\title{
Artificial aeration promotes better zootechnical performance and physiological balance of tambaqui (Colossoma macropomum) cultivated in a system without continuous water flow (Amazon: Brazil)
}

\section{Aeração artificial promove melhor desempenho zootécnico e equilíbrio fisiológico do tambaqui (Colossoma macropomum) cultivado em sistema sem fluxo contínuo de água (Amazônia: Brasil)}

Aireación artificial promueve un mejor rendimiento zootécnico y equilibrio fisiológico del tambaqui (Colossoma macropomum) cultivado en un sistema sin flujo continuo de agua (Amazonía: Brasil)

Marlos Oliveira Porto ORCID: https://orcid.org/0000-0002-9398-0065 Universidade Federal do Acre, Brazil Universidade Federal de Rondônia, Brazil E-mail: marlosporto@unir.br Jucilene Cavali

ORCID: https://orcid.org/0000-0002-2069-4543 Universidade Federal do Acre, Brazil Universidade Federal de Rondônia, Brazil E-mail: jcavali@unir.br

Ivan Dias de Medeiros ORCID: https://orcid.org/0000-0002-7035-0239 Universidade Federal de Rondônia, Brazil E-mail: id_medeiros@hotmail.com

Maiza Oliveira Soares

ORCID: https://orcid.org/0000-0002-0773-1899 Universidade Federal de Rondônia, Brazil E-mail: maizaaoliveira@gmail.com Jerônimo Vieira Dantas Filho ORCID: https://orcid.org/0000-0002-5965-9438 Universidade Federal do Acre, Brazil E-mail: jeronimovdantas@gmail.com

Antônio Marcos Ferreira ORCID: https://orcid.org/0000-0003-2902-4121 Universidade Federal de Rondônia, Brazil E-mail: ferreira.ameng@gmail.com

Ademilson de Assis Dias ORCID: https://orcid.org/0000-0001-9035-6075 Universidade Federal de Rondônia, Brazil E-mail: ademilson.dias@unir.br

Santina Rodrigues Santana ORCID: https://orcid.org/0000-0002-3920-5885 Universidade Federal de Rondônia, Brazil E-mail: santina@unir.br

\begin{abstract}
The aimed of the study was to evaluate the effect of continuous artificial aeration on zootechnical performance, hematological characteristics and glucose concentration of tambaqui (Colossoma macropomum) cultivated in a system without water flow. The study was conducted with two treatments, with aeration and without artificial aeration. Were 600 tambaqui juveniles with an average initial weight of $15 \pm 0.15 \mathrm{~g}$ were distributed in two excavated tanks. Thirty fish were captured per cultivation unit to perform monthly biometric measurements and were subjected to blood collection to determine hematological parameters. There was no difference between hematological variables $(\mathrm{p}<0.05)$. However, the continuous use of artificial aeration provided fish with more comfortable conditions, resulting in greater performance $(\mathrm{p}<0.05)$ in up to 90 days of cultivation, with an average daily weight gain of $4.82 \mathrm{~g}$ compared to $4.49 \mathrm{~g}$ to the system without artificial aeration. It can be inferred that fish
\end{abstract}


grown in a system without artificial aeration presented, when compared to those raised in a system with continuous artificial aeration, smaller values $(\mathrm{p}<0.05)$ of growth, both in weight and in length, consequently the continuous use of the aerator provided favorable conditions for the fish, resulting in average daily weight gain and total biomass gain.

Keywords: Aerator; Fish farm; Hematology of fish; Zootechnical performance.

\section{Resumo}

O objetivo do estudo foi avaliar efeito da aeração artificial contínua sobre o desempenho zootécnico, características hematológicas e concentração de glicose do tambaqui (Colossoma macropomum) cultivado em sistema sem fluxo de água. O estudo foi conduzido com dois tratamentos, com aeração e sem aeração artificial. Foram distribuídos 600 juvenis de tambaqui com peso inicial médio de $15 \pm 0,15 \mathrm{~g}$ em dois tanques escavados. Foram capturados 30 peixes por unidade de cultivo, para realização das medidas biométricas mensais e submetidos à coleta de sangue para determinação dos parâmetros hematológicos. Não houve diferença entre as variáveis hematológicas $(\mathrm{p}<0.05)$. Contudo, o uso contínuo da aeração artificial proporcionou condições mais confortáveis aos peixes, resultando em maior desempenho $(\mathrm{p}<0.05)$ em até 90 dias de cultivo, com média de ganho de peso diário de 4,82 g comparado a 4,49 g ao sistema sem aeração artificial. Pode-se inferir que os peixes cultivados em sistema sem aeração artificial apresentaram, quando comparado com aqueles criados em sistema com aeração artificial contínua valores menores $(\mathrm{p}<0.05)$ de crescimento, tanto em peso como em comprimento, consequentemente o uso contínuo do aerador proporcionou condições favoráveis para os peixes, resultando em ganho de peso médio diário e ganho de biomassa total.

Palavras-chave: Aerador; Desempenho zootécnico; Hematologia de peixes; Piscicultura.

\section{Resumen}

El objetivo de la investigación fue evaluar el efecto de la aireación artificial continua sobre el desempeño zootécnico, las características hematológicas y la concentración de glucosa de tambaqui (Colossoma macropomum) cultivado en un sistema sin flujo de agua. La investigación se realizó con dos tratamientos, con aireación y sin aireación artificial. Se distribuyeron 600 juveniles de tambaqui con un peso inicial promedio de $15 \pm 0.15 \mathrm{~g}$ en dos tanques excavados. Se capturaron 30 peces por unidad de cultivo para realizar mediciones biométricas mensuales y se sometieron a extracción de sangre para determinar parámetros hematológicos. No hubo diferencia entre las variables hematológicas $(\mathrm{p}<0.05)$. Sin embargo, el uso continuo de aireación artificial brindó a los peces condiciones más cómodas, resultando en un mayor rendimiento $(\mathrm{p}<0.05)$ en hasta 90 días de cultivo, con una ganancia de peso diaria promedio de $4.82 \mathrm{~g}$ frente a $4.49 \mathrm{~g}$ al sistema sin aireación artificial. Se puede inferir que los peces criados en un sistema sin aireación artificial presentaron, al compararlos con los criados en un sistema con aireación artificial continua, valores menores $(\mathrm{p}<0.05)$ de crecimiento, tanto en peso como en longitud, consecuentemente el uso continuo de El aireador proporcionó condiciones favorables para los peces, lo que resultó en una ganancia de peso diaria promedio y una ganancia de biomasa total.

Palabras clave: Aireador; Hematología de peces; Piscicultura; Rendimiento zootécnico.

\section{Introduction}

Several native Brazilian fish arouse the interest of fish farmers and researchers due to the characteristics of fast growth, high feeding efficiency, ease of induced reproduction and characteristics appropriate to cultivation (Chamy et al., 2015). Among the fish native to the Amazon, tambaqui (Colossom macropomum Cuvier, 1018) stands out, which is the most cultivated fish species in the Amazon region (Cavali et al., 2020). Its meat is highly appreciated by the local population, making its demand high, which is why many scholars and producers have intensified efforts to establish an appropriate cultivation system for the species (Porto et al., 2020).

Other factors that motivated the creation of C. macropomum in the Amazon, were the easy obtaining of juveniles, the high growth potential, the use of primary natural food, and the high productivity and rusticity (Chamy et al., 2015; Martins et al., 2020). The consumption of fish in Brazil grows, surpassing the annual per capita consumption of $14 \mathrm{~kg}$ per inhabitant, which surpassed that recommended by the World Health Organization (WHO), $12 \mathrm{~kg}$ per inhabitant per year (FAO, 2018). The tambaqui corresponded to about $29 \%$ of the national fish production, in the Amazon it corresponded to more than two thirds of the creations (Peixe BR, 2020). As a result, the growing demand for commercially sized fish has contributed to the development of fish farming (Martins et al., 2020). 
Despite this large production scenario, there is a lack of engineering technologies for intensive systems in line with the production of tambaqui. For, there is an emerging demand for the application of studies and technologies in production systems, such as studies of the physiological response of tropical fish in stressful farming environments. Thus, the improvement of production techniques implies the need to increase studies that generate information on the improvement of Amazonian fish farming systems (Aerts et al., 2015).

Among the various technologies adopted in the cultivation of tambaquis in order to optimize productivity, artificial aeration has received great prominence. Because it can provide improvements in the quality of cultivation water, improvements in productive zootechnical performance, higher survival rates and the possibility of increasing the support capacity of the cultivation environment (Lima et al., 2015). Aeration, together with good management practices in fish farming, are necessary, since oxygen dissolved in water is an important factor in the fish farming system. The use of aerators provides homogenization of oxygen distribution in water, avoiding environmental stress and mortality (Tanveer et al., 2018). Thus, homeostasis related to some blood parameters can be influenced by the availability of oxygen in the aquatic environment.

The hematological parameters can be used as tools for diagnosing diseases, indicators of physiological, nutritional status and handling stress (Silva et al., 2016). And yet, the study of blood cells is a fundamental tool for diagnosing infectious diseases, leukemias and crop stress (Garcia-Navarro, 2005; Chamy et al., 2015). To determine the animal's health conditions through blood components, it is necessary to delimit the normal ranges of values for the species (Tavares-Dias et al., 2008). This normality, however, is relative, since variations in values can be observed according to age, sex, genetic factors, environmental and nutritional changes (Ranzani-Paiva et al., 2013). The standardization of fish hematological parameters helps in determining the influences of diets, illnesses and other situations of environmental stress (Ozovehe, 2013). Likewise, changes in these parameters contribute to the diagnosis of morbid conditions that affect fish.

The aimed of this study was to evaluate the effect of continuous artificial aeration on zootechnical performance, hematological characteristics and glucose concentration of tambaqui (Colossoma macropomum) cultivated in a system without continuous water flow.

\section{Material and Methods}

The study was conducted at the Carlos Eduardo Matiaze Center for Fish Studies, Universidade Federal de Rondônia, Campus de Presidente Médici. This study is characterized as an experimental one by testing variables related to water quality and fish welfare (Pereira et al., 2018). For this, data were obtained from 600 fish with a body weight of $15 \pm 0.15 \mathrm{~g}$ distributed in two excavated tanks of $100 \mathrm{~m}^{2}$ without water renewal. The fish were submitted to two systems, one with artificial aeration and the other without artificial aeration system.

The water renewal in the breeding tanks was carried out to replace the losses due to infiltration and evaporation. Thus, floating aerators operated for 24 hours at 12/12 hour intervals were used. The fish were fed manually at the frequency of three daily treatments at $7 \mathrm{am}, 12 \mathrm{pm}$ and $6 \mathrm{pm}$ with artificial feed for omnivorous fish. The biestries were performed at 30, 60 and 90 days of cultivation in $10 \%$ of the population. For the cultivation phases, the grain size of the feed pellets was adjusted to 2.3 $\mathrm{mm} ; 4.6 \mathrm{~mm}$ and $8-10 \mathrm{~mm}$ in diameter, the crude protein content at 36,32 and $28 \%$ and the feed supply at 6,4 and $2 \%$ of body weight with weekly adjustments based on consumption calculations for the rates of fish growth.

The water quality of the tanks was analyzed monthly, of hydrogen potential $(\mathrm{pH})$, oxygen dissolved in water (ODW), alkalinity, hardness, temperature, conductivity, total ammonia and transparency, using a multiparameter probe (Oliveira et al., 2010). The average daily weight gain, apparent feed conversion and apparent consumption were calculated. In each cultivation 
phase, 30 animals from each treatment were sampled through a harvesting net and individual blood samples were taken. In biometries, weight, standard body length, height and back circumference were measured.

Blood collection was performed by averages of an inclined insertion around 45 degrees in the belly (Goldenfarb et al., 1971). The total volume collected was $6 \mathrm{~mL}$ of blood from each individual; $2 \mathrm{~mL}$ for the erythrogram, $2 \mathrm{~mL}$ for glucose analysis and $2 \mathrm{~mL}$ for the realization of total proteins (Pádua et al, 2013). The samples were homogenized and stored in a thermal box with ice. The hematological variables were calculated from Hematocrit (Chamy et al., 2015). From the averages of erythrocytes, hemoglobin rate and hematocrit percentage, hematimetric indices, mean corpuscular volume (CMV) and mean corpuscular hemoglobin (HCM) were calculated.

The glucose concentration analysis was performed using the GOD-Trinder Labtest method for Glucose Liquiform. The test uses pH 7.5 buffer, phenol, glucose oxidase, peroxidase, 4-aminoantipyrine, sodium azide and surfactants, stored at 2 to $-8^{\circ} \mathrm{C}$, centrifuged for five minutes in order to separate blood plasma from red blood cells and, in $0.01 \mathrm{~mL}$ of the blood sample added, $0.01 \mathrm{~mL}$ of the Standard sample (contains glucose and non-toxic biocide) and $1.0 \mathrm{~mL}$ of the reagent.

The averages obtained in treatments with artificial aeration and without artificial aeration were compared by Student's T test, with a significance level of 5\%. To perform the statistical analyzes, the Genes software was used (Cruz, 2013).

\section{Results}

The averages of the water temperature and the concentration of oxygen dissolved in water (ODW) in the cultivation phases, showed a significant difference between the nurseries with aeration and without aeration (control). However, the pH showed no difference with artificial aeration $(\mathrm{p}>0.05)$ (Table 1).

Table 1 - Averages values of ODW, temperature, $\mathrm{pH}$, coefficient of variation and probability (P-value), in tanks with aeration and without artificial aeration (Control).

\begin{tabular}{ccccc}
\hline Variable & \multicolumn{2}{c}{ Treatment } & p-value & CV $(\%)^{1}$ \\
\cline { 2 - 3 } & Artificial Aerated & $\begin{array}{c}\text { Not aerated } \\
(\text { Control })\end{array}$ & & \\
\hline ODW $\left(\mathrm{mg} \mathrm{dL}^{-1}\right)$ & $6.35 \mathrm{a}$ & $3.56 \mathrm{~b}$ & $<0.0001$ & 27.13 \\
Temperature $\left({ }^{\circ} \mathrm{C}\right)$ & $29.24 \mathrm{a}$ & $30.4 \mathrm{~b}$ & $<0.0001$ & 2.80 \\
$\mathrm{pH}$ & $8.06 \mathrm{a}$ & $7.90 \mathrm{a}$ & $<0.0796$ & 3.94 \\
Total ammonia $\left(\mathrm{ug} \mathrm{L}^{-1}\right)$ & $1.00 \mathrm{a}$ & $1.93 \mathrm{~b}$ & $<0.0160$ & 6.80 \\
\hline
\end{tabular}

Averages on the line followed by different letters $(a, b)$, differ by Student's t test at $5 \%$ probability. ${ }^{1}$ Coefficient of variation. Source: Authors.

The values of the total ammonia concentration showed an average value of $1.0 \mathrm{ug} \mathrm{L}^{-1}$ in the treatment with aeration and 1.93 in the treatment without aeration (control) $1.93 \mathrm{ug} \mathrm{L}^{-1}$ in the water at 90 days of culture.

The artificial aeration provided average levels of ODW higher by 43.4 and $71.3 \%$ at 30 and 60 days of cultivation, the averages obtained in the nursery without aeration (control) 9.2 and $2.4 \%$, respectively. The ODW contents in the aerated tank ranged from 5.82 to $6.2 \mathrm{mg} \mathrm{L}^{-1}$ whereas in the non-aerated tank, the variations in measurements were 1.8 to $3.16 \mathrm{mg} \mathrm{L}^{-1}$ (Figure 1a). The artificial aeration provided less variation in temperature and ODW values in water compared to the nonaerated nursery (control) $(\mathrm{P}<0.05)$.

The water temperature was higher between $2 \mathrm{pm}$ and $3 \mathrm{pm}$ and milder between 8 am and 9 am, in the two rearing tanks. The maximum averages of the measured temperatures were 32.4 and $32.3{ }^{\circ} \mathrm{C}$ of the 30 and 60 days of cultivation, respectively, tank without aeration (control) was of $30.8^{\circ} \mathrm{C}$ and $29.5^{\circ} \mathrm{C}$ in the tank with artificial aeration (Figure $1 \mathrm{~b}$ ). 
Figure 1 - Nictemeral evaluation, ODW, temperature and water $\mathrm{pH}$ of tanks with artificial aeration (CAA) in without aeration (control) (SAA) at 30 and 60 days of cultivation.

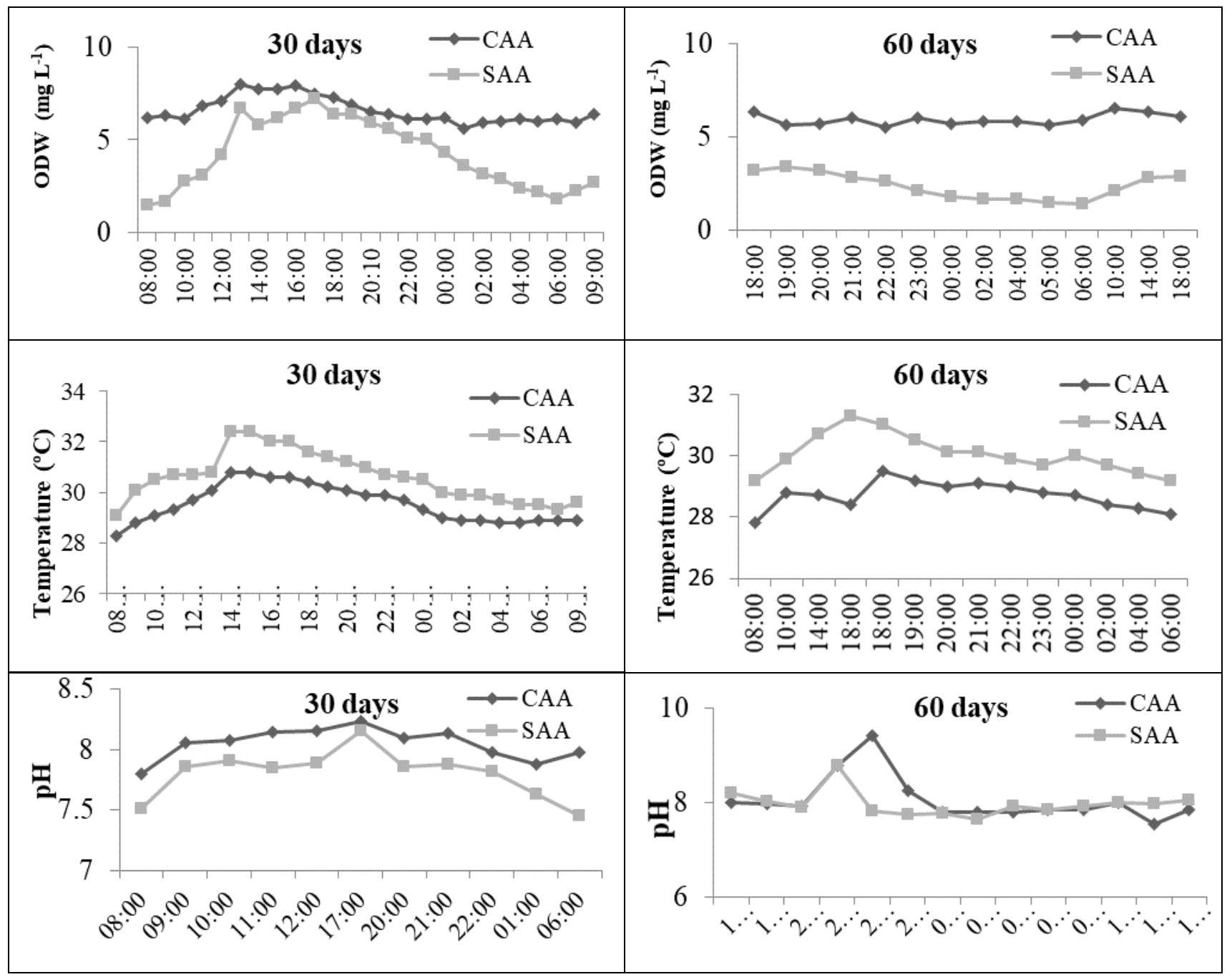

Source: Authors.

The concentration of ODW is inversely proportional to temperature and directly proportional to atmospheric pressure, varying throughout the day depending on photosynthesis and phytoplanktonic respiration. What was observed at 2 pm when the temperature peaked while ODW concentrations were lower (Figure 1a). At 60 days of cultivation, the temperature varied between 27.8 and $32.4{ }^{\circ} \mathrm{C}$ in the two tanks with aeration and without aeration, and the ODW concentration remained below 2 $\mathrm{mg} \mathrm{L}^{-1}$ from $11 \mathrm{pm}$ to $6 \mathrm{am}$ in the tank without aeration (control). Below this value, the tambaqui starts to depress the metabolic rate, and can consequently reduce the productive and reproductive performance. This situation occurs frequently in a cultivation tank with reduced water renewal, which may be temporary or permanent, depending on environmental conditions.

The ODW values are presented for the tank with mechanical aeration between 30 and 60 days of cultivation and for the nursery without aeration in the phase with 60 days between 12 am and 12 pm, thus, the environment with artificial aeration presented favorable concentrations for fish farming.

For the tank with artificial aeration, the $\mathrm{pH}$ values ranged from 6.98 to 8.25 for routine measurements, and for the tank without aeration, the values ranged from 6.17 to 7.92 . The highest values for $\mathrm{pH}$ were recorded between $5 \mathrm{pm}$ and $6 \mathrm{pm}$ in the two rearing tanks. And, at 30 and 60 days of cultivation, the highest values were between 9 pm and 10 pm for both tanks with and without aeration, with a maximum value of 9.43 for the tank with aeration. The greater stability of limnological parameters 
generates less energy expenditure for body regulation and adaptation to environmental conditions, resulting in greater weight gain.

Fish removed from the tank without aeration had a smaller size and weight compared to those in the tank with artificial aeration, thus, the oxygen consumption by fish in the tank without aeration decreased the concentration of ODW, causing the fish to seek oxygen on the surface and large part of the fish had developed lip prolapse, which indicates low ODW content. The fish distribution shows a concentration of individuals closer to the average of the lot in the fish that were in the tank with aeration.

At night there was a deficit in ODW (Figure 8), the most critical period occurring between 2 am and 6 am, when ODW levels suddenly drop from 3.20 to $1.80 \mathrm{mg} \mathrm{L}^{-1}$ in cultivation without aeration (Figure 2).

Figure 2 - Nictemeral variation of ODW in aerated and non-aerated (control) tambaqui cultivation at 90 days of cultivation.

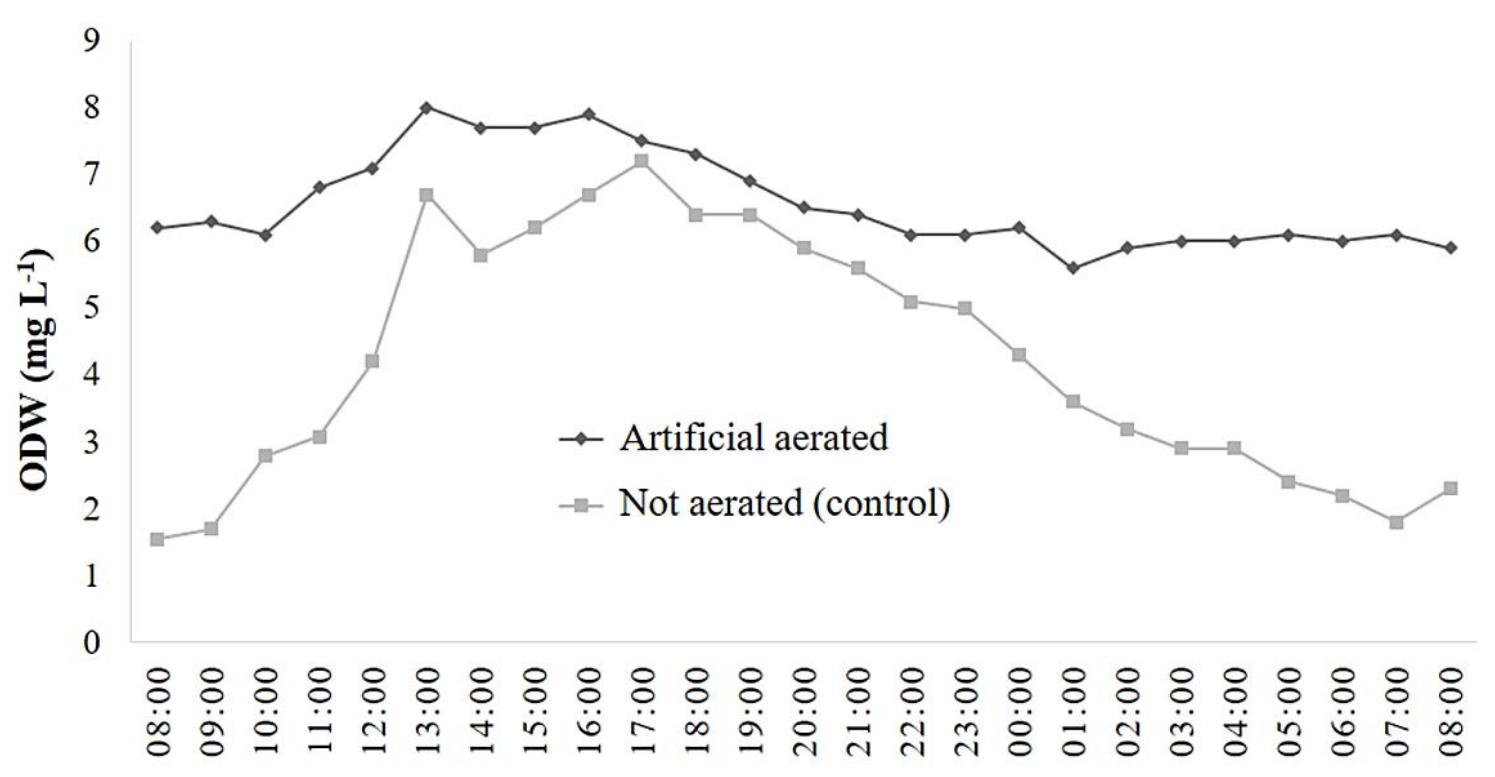

Source: Authors.

The biggest differences in the biometric parameters of the fish occurred at 60 days of experiment $(\mathrm{p}<0.05)$. However, at 30 days of cultivation only the body length varied significantly, and for this phase of cultivation, there was greater growth in the lengths of the animals under a culture system with artificial aeration (Table 2). At 60 days of experiment, the treatment with artificial aeration obtained the greatest growth, given by the parameters, body length, total and head, height and body weight $(\mathrm{p}<0.05)$. However, at 90 days of experiment there was no difference for treatments with and without aeration for most biometric performance parameters ( $p>0.05$ ), except for the total length (Table 2).

The apparent daily consumption was similar in both treatments $(\mathrm{p}<0.05)$. Ranging from 7.98 to $10.58 \mathrm{~g}$ in the treatment with artificial aeration and 7.93 and $10.45 \mathrm{~g}$ in the treatment without aeration (control) (Table 2). The average values of daily weight gain varied from 4.49 to $4.82 \mathrm{~g} \mathrm{day}^{-1}$ for treatments with and without aeration (Table 2). The weight gain of 4.5 $\mathrm{g} \mathrm{day}^{-1}$ for tambaquis in a semi-intensive system and fed with commercial rations containing between 28 to $32 \%$ Crude protein was enough to supply their needs.

Apparent consumption rates ranged from 2.19 to 2.33 (Table 2). Although there was no difference between systems with and without aeration $(\mathrm{p}<0.05)$. The rate of feed conversion increased the growth of the fish, less efficient in using the 
Research, Society and Development, v. 10, n. 1, e32310111759, 2021 (CC BY 4.0) | ISSN 2525-3409 | DOI: http://dx.doi.org/10.33448/rsd-v10i1.11759

food. The use of technologies that improve physiological and environmental conditions, such as water quality and stocking density, are important to explore the maximum gain potential in each phase of cultivation.

Among the blood variables, no statistical difference ( $p>0.05)$ was observed in tambaquis kept in a culture system with artificial aeration when compared to fish grown in the system without aeration (control) (Table 3). At 30, 60 and 90 days, average values of $3.99,3.82$ and $4.13 \times 106 \mu \mathrm{L}^{-1}$ were observed for erythrocytes and $11.52,11.07$ and $12.09 \times 106 \mu \mathrm{L}^{-1}$ for hemoglobin, respectively, not significant influence of the aeration system for these variables (Table 3 ). 


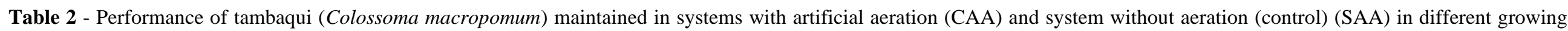
periods.

\begin{tabular}{|c|c|c|c|c|c|c|c|c|c|c|c|c|c|c|}
\hline \multirow[t]{2}{*}{ Variables } & \multicolumn{2}{|c|}{ Day zero } & \multicolumn{4}{|c|}{30 days } & \multicolumn{4}{|c|}{60 days } & \multicolumn{4}{|c|}{90 days } \\
\hline & Initial & $\begin{array}{l}\mathrm{CV} \\
(\%)^{1}\end{array}$ & CAA & SAA & Average & $\mathrm{CV}(\%)^{1}$ & CAA & SAA & Average & $\begin{array}{l}\text { CV } \\
(\%)^{1}\end{array}$ & CAA & SAA & Average & $\begin{array}{l}\mathrm{CV} \\
(\%)^{1}\end{array}$ \\
\hline Overall length $(\mathrm{cm})$ & 24.2 & 9.0 & $29.13 \mathrm{a}$ & $28.71 \mathrm{a}$ & 28.92 & 5.60 & $37.73 \mathrm{a}$ & $31.56 \mathrm{~b}$ & 32.15 & 6.14 & $31.3 \mathrm{a}$ & $29.6 b$ & 30.45 & 6.86 \\
\hline Head length $(\mathrm{cm})$ & 6.8 & 9.1 & $7.3 \mathrm{a}$ & $6.85 \mathrm{~b}$ & 7.07 & 9.08 & $9.21 \mathrm{a}$ & $8.82 \mathrm{~b}$ & 9.02 & 8.62 & $8.67 \mathrm{a}$ & $8.46 \mathrm{a}$ & 8.56 & 7.53 \\
\hline Height $(\mathrm{cm})$ & 9.7 & 8.0 & $12.55 \mathrm{a}$ & $12.63 \mathrm{a}$ & 12.59 & 6.48 & $14.9 \mathrm{a}$ & $14.36 \mathrm{~b}$ & 14.63 & 5.76 & $14.23 \mathrm{a}$ & $13.96 a$ & 14.1 & 7.47 \\
\hline Circumference $(\mathrm{cm})$ & 19.6 & 8.4 & $25.08 \mathrm{a}$ & $25.38 \mathrm{a}$ & 25.23 & 6.37 & $26.8 \mathrm{a}$ & $26.55 \mathrm{a}$ & 26.67 & 6.36 & $29.2 \mathrm{a}$ & $28.63 \mathrm{a}$ & 28.92 & 5.44 \\
\hline Body weight (g) & 235.7 & 26.8 & $428 \mathrm{a}$ & $430.3 b$ & 429.5 & 16.36 & $582 \mathrm{a}$ & $523.2 \mathrm{~b}$ & 552.6 & 17.7 & $660.1 \mathrm{a}$ & $631.0 \mathrm{~b}$ & 645.6 & 15.72 \\
\hline Average gain $\left(\mathrm{g} \mathrm{day}^{-1}\right)$ & - & - & $5.35 \mathrm{a}$ & $5.40 \mathrm{a}$ & 5.37 & 12.7 & $5.86 \mathrm{a}$ & $4.87 \mathrm{~b}$ & 5.37 & 14.2 & $4.82 \mathrm{a}$ & $4.49 \mathrm{a}$ & 4.66 & 10.7 \\
\hline Apparent consumption $\left(\mathrm{g} \mathrm{day}^{-1}\right)$ & - & - & $7.98 \mathrm{a}$ & $7.93 \mathrm{a}$ & 7.95 & 10.2 & $9.28 \mathrm{a}$ & $9.15 \mathrm{~b}$ & 9.21 & 10.9 & $10.58 \mathrm{a}$ & $10.45 \mathrm{a}$ & 10.51 & 8.8 \\
\hline Apparent feed conversion & - & - & $1.48 \mathrm{a}$ & $1.48 \mathrm{a}$ & 1.48 & 11.7 & $1.58 \mathrm{a}$ & $1.88 \mathrm{~b}$ & 1.72 & 13.6 & $2.19 \mathrm{a}$ & $2.33 \mathrm{a}$ & 2.26 & 10.2 \\
\hline
\end{tabular}

Averages on the line followed by different letters $(a, b)$, differ by Student's $t$ test at $5 \%$ probability. ${ }^{1}$ Coefficient of variation.

Source: authors's file.

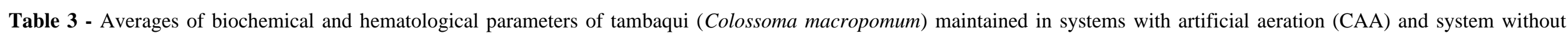
aeration (control) (SAA) in different growing seasons.

\begin{tabular}{|c|c|c|c|c|c|c|c|c|c|c|c|c|c|c|}
\hline \multirow[t]{2}{*}{ Variables } & \multicolumn{2}{|c|}{ Day zero } & \multicolumn{4}{|c|}{30 days } & \multicolumn{4}{|c|}{60 days } & \multicolumn{4}{|c|}{90 days } \\
\hline & Initial & $\mathrm{CV}(\%)^{1}$ & CAA & SAA & Average & $\begin{array}{l}\mathrm{CV} \\
(\%)^{1}\end{array}$ & CAA & SAA & Average & $\begin{array}{l}\mathrm{CV} \\
(\%)^{1}\end{array}$ & CAA & SAA & Average & $\mathrm{CV}(\%)^{1}$ \\
\hline Erythrocytes $\left(10^{6} \mu \mathrm{L}^{-1}\right)$ & 4.08 & 7.42 & $3.92 \mathrm{a}$ & $3.99 \mathrm{a}$ & 3.99 & 8.16 & $3.82 \mathrm{a}$ & $3.82 \mathrm{a}$ & 3.82 & 8.92 & $4.12 \mathrm{a}$ & $4.14 \mathrm{a}$ & 4.13 & 5.18 \\
\hline Hemoglobin $\left(\mathrm{g} \mathrm{dL}^{-1}\right)$ & 11.93 & 8.46 & $11.41 \mathrm{a}$ & $11.64 \mathrm{a}$ & 11.52 & 9.29 & $11.07 \mathrm{a}$ & $11.07 \mathrm{a}$ & 11.07 & 10.16 & $12.05 \mathrm{a}$ & $12.12 \mathrm{a}$ & 12.09 & 5.85 \\
\hline Hematocrit (\%) & 35.79 & 8.46 & $34.23 \mathrm{a}$ & $34.9 \mathrm{a}$ & 34.56 & 9.34 & $33.2 \mathrm{a}$ & $33.21 \mathrm{a}$ & 33.2 & 10.26 & $36.17 \mathrm{a}$ & $36.37 \mathrm{a}$ & 36.27 & 5.89 \\
\hline $\operatorname{VCM}\left(\mu \mathrm{m}^{-3}\right)^{3}$ & 87.67 & 1.21 & $87.23 \mathrm{a}$ & $67.41 \mathrm{~b}$ & 67.32 & 1.55 & $66.77 \mathrm{a}$ & $66.79 a$ & 66.78 & 1.53 & $88.00 \mathrm{a}$ & 87.96 a & 87.98 & 0.68 \\
\hline $\mathrm{HCM}\left(\mathrm{pg} \mathrm{cel}^{-1}\right)^{2}$ & 29.22 & 1.21 & $29.05 \mathrm{a}$ & $29.10 \mathrm{a}$ & 29.10 & 1.48 & $28.94 \mathrm{a}$ & $28.94 \mathrm{a}$ & 28.94 & 1.41 & $29.29 \mathrm{a}$ & $29.32 \mathrm{a}$ & 29.30 & 0.72 \\
\hline Glucose $\left(\mathrm{mg} \mathrm{dL}^{-1}\right)$ & 119.2 & - & $77.18 \mathrm{a}$ & $70.42 \mathrm{~b}$ & 73.80 & 18.26 & $124.58 \mathrm{a}$ & $164.54 \mathrm{~b}$ & 144.56 & 37.93 & $90.44 \mathrm{a}$ & $101.40 \mathrm{~b}$ & 95.92 & 24.80 \\
\hline
\end{tabular}

Averages on the line followed by different letters (a,b), differ by Student's t test at $5 \%$ probability. ${ }^{1}$ Coefficient of variation.

Source: Author. 
The decrease in red blood cell count and hematocrit percentage indicates worsening of fish health problems and the maximum coefficient of variation $(\mathrm{CV} \%)$ of the erythrocyte count $8.92 \%$, hemoglobin $10.16 \%$, hematocrit $10.26 \%$, VCM $1.55 \%$ and HCM $1.48 \%$ was low, ensuring greater homogeneity between data groups (Table 3).

The hematimetric indices VCM and HCM were not altered by treatments with and without aeration ( $\mathrm{p}>0.05$ ). However, the VCM and HCM indices must be interpreted with caution, as they are calculated from the total erythrocyte count, which can present a margin of error (McCarthy et al., 1973). Although hematological variables did not differ ( $p>0.05$ ), ODW in the treatment without aeration was low. Consequently, the treatment without aeration provided less comfortable conditions for the fish.

There was no difference for the results of blood glucose concentration in phases I and III, 30 and 90 days ( $\mathrm{p}>0.05$ ). For collection at 60 days of cultivation, the results differed for tanks with aeration and without artificial aeration $(\mathrm{p}<0.05)$ (Table 4). Despite the less favorable conditions in which the animals in the tank were submitted without aeration in relation to the conditions of the tank with artificial aeration, in view of the ODW content, temperature and pH. In culture systems, the averages values for glucose concentration were the same. Probably, it may have been due to the initial stress caused by artificial aeration, since, at 60 days of cultivation, the values showed the opposite, mechanical aeration was comfortable for the fish.

At 60 days of cultivation, there was a statistical difference $(p>0.05)$ between the culture systems, with higher concentrations of glucose being observed for fish that were in the tank without aeration (control), thus suggesting that these animals were raised with an ODW deficit, that is, they could possibly be in a condition of stress. However, at 60 days of cultivation the average glucose value for fish in the tank with aeration and without aeration did not differ in terms of glucose concentration with an average value of $95.92 \mathrm{mg} \mathrm{L}^{-1}$. For glycemia, the most representative class was the $81-120 \mathrm{mg}^{-1}$ $(\mathrm{n}=13)$, followed by class $121-160 \mathrm{mg} \mathrm{dL}^{-1}(\mathrm{n}=11)$ and the least representative class was $201-240 \mathrm{mg} \mathrm{dL}^{-1}(\mathrm{n}=1)$.

The results for glucose showed a higher concentration of fish in the class of $40-80 \mathrm{mg} \mathrm{dL}^{-1}$ for both the tank with artificial aeration and the one without aeration $(n=23$ and $n=20)$ with average glucose values within these classes of 77.13 and $70.42 \mathrm{mg} \mathrm{dL}^{-1}$ for tank with artificial aertation and without aeration. 
Figure 3 - Glucose levels at tambaqui (Colossomo macropomum) maintained at 30, 60 and 90 days of cultivation in tanks with artificial aeration (CAA) and without aeration (control) (SAA).

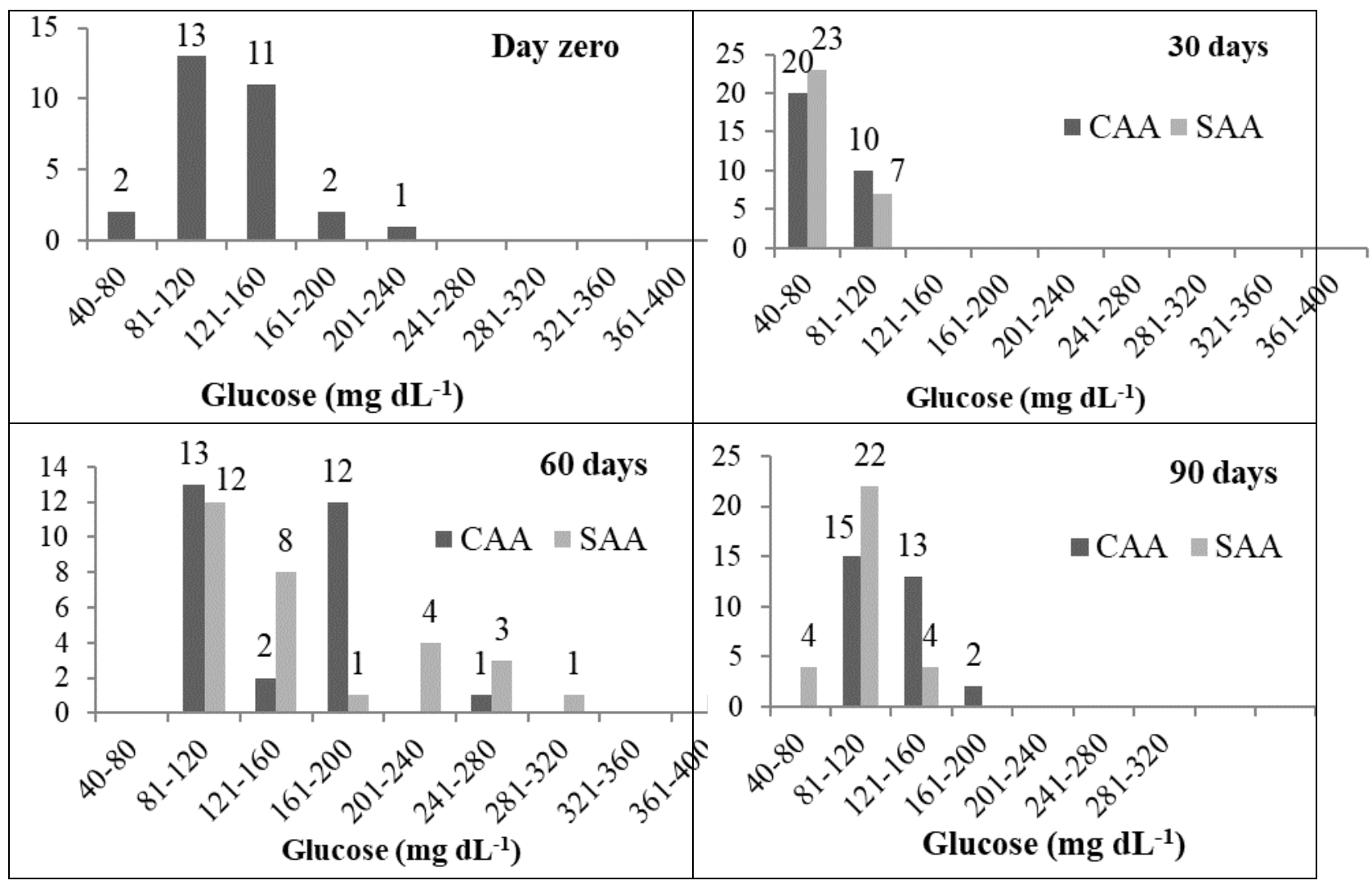

Source: Authors.

At 60 days of cultivation, glucose levels varied considerably from the previous collection with the presence of seven of the nine classes. The class with the largest number of individuals was $81-120 \mathrm{mg} \mathrm{dL}^{-1}(\mathrm{n}=13$ and $\mathrm{n}=12)$ in both cultivation systems. The classes $281-320$ and $361-400 \mathrm{mg} \mathrm{dL}^{-1}$ were the least representative and presented the same value of individuals $(\mathrm{n}=1)$ for the tank without aeration (control). At 90 days of cultivation, glucose values varied less compared to the previous phase and only four classes were represented. The class with the largest number of individuals was $81-120 \mathrm{mg} \mathrm{dL}^{-1}$ ( $\mathrm{n}=15$ and $\mathrm{n}=22$ ) for nurseries with aeration and without aeration, followed by class $121-160 \mathrm{mg} \mathrm{dL}^{-1}$ ( $\mathrm{n}=13$ and $\left.\mathrm{n}=4\right)$ in both tanks(Figure 3).

Regarding the relevance of water quality parameters, it can be said that they are crucial to the success in cultivating tambaqui, this study is proof of this information. Therefore, the limnological values obtained, such as $\mathrm{pH}$ and temperature, oscillated within the ranges considered appropriate for the cultivation of tambaqui (Table 1) (Silva et al., 2013). Assessing the tambaqui's physiological responses, there was no mortality of individuals at concentrations of $\mathrm{pH} 4.0$, to 8.0, however $\mathrm{pH}$ close to 8.0 changed the hematological parameters (Aride et al., 2017).

The increase in conductivity levels throughout the study may be associated with an increase in organic matter in the water, from fish excreta and surplus feed (Oliveira et al., 2012). The ODW concentrations below $2.0 \mathrm{mg} \mathrm{L}^{-1} \mathrm{impaired}$ the growth of tambaqui (Aride et al., 2017). It harms it due to the effects of hypoxia, causing crop stress (Silva et al., 2013).

\section{Discussion}

Due to the growing demand for fish in the Amazon, the volume of fish production has intensified, however, the tambaqui confined to high densities without efficient aeration tend to have a physiological and immunological imbalance, in 
addition to insufficient protein deposition, that is, insufficient weight gain (Vikesa et al., 2017). The physiological, hematological and immune conditions of the tambaquis are directly related to well-being in the culture media and correlated with the deposition of muscle proteins, as they are correlated with the performance and gain of body mass ( $\mathrm{Paz} \& \mathrm{Val}, 2018$ ).

When the culture conditions are favorable, that is, when there is biochemical and physiological stability, greater deposition of proteins occurs, because the cell membranes release fat, increasing the concentrations of free fatty acids in the fluids and are converted into acetyl-CoA, which is used as an energy source, which saves proteins, leading them to growth and fattening (Sampaio \& Freite, 2016). Thus, protein consumption is directed towards somatic, muscle and bone growth (Bjornsson et al., 2002; Fuentes et al., 2013). Studies on stress conditions pointed to a greater targeting of energy obtained from food to maintain physiological balance and, to a lesser extent, for growth (Schmidt-Nielsen, 1996). This can justify the significant differences for body weight, total length, standard length, head length and height between the control group in relation to treatment. In order to prove, the feed conversion index is used, which can be used as an indicator of the quality and supply of the feed (Aride et al., 2017), as it represents the efficiency of the conversion of food into biomass (Cerdeira et al., 2018).

The nitrogen compounds come mainly from animal excretion and food leftovers during the growing period, which may exceed the values recommended in the literature, due to high density and the supply of feed in intensive systems (Oliveira et al., 2012). The breeding tanks tambaqui with high biomass without constant artificial aeration have high concentrations of total ammonia, which causes a reduction in the flow of oxygen in the blood stream of the tambaqui, affecting the gas exchange of branchial ventilation, decreasing the $\mathrm{Fe}^{3+}$ affinity erythrocytes, which brings down the hematocrit percentage (Paz \& Val, 2018). Likewise, glucose levels in cell plasma and also in $\mathrm{Na}^{+}, \mathrm{K}^{+}$and ATPase activity can be affected, which can be reduced due to poor ODW distribution, negatively influencing osmotic balance and amino acid transport, blood flow enthalpy and the functional stability of vital organs. These factors cause the apathy of metabolism and protein synthesis (Baldisserotto, 2013). Therefore, investment in artificial aeration is crucial to avoid animal stress due to hypoxia. Likewise, Silva (2016) found that in ponds with good artificial aeration even fish confined to high densities the average feed consumption is stable, avoiding waste of feed, which is beneficial for water quality, as it prevents eutrophication and hypoxia.

The hyperglycemia is an indicator parameter of response to acute or chronic stress resulting from the increased energy demand suffered by fish. Azevedo et al. (2016) evaluated systems with and without aeration in the creation of tambaqui, and observed hyperglycemia in fish reared without aeration. These same authors found that both conditions showed that biomass was the item that most influenced the limnological, biochemical and hematological parameters. With the increasing increase in hyperglycemia, it was necessary to increase the hours of aeration and feed supply. The increase in hyperglycemia also occurs in hypoxia, less water transparency, lower ODW and very acidic or very alkaline pH (Silva \& Fujimoto, 2015). This is evidenced because the greater biomass consumes more food and more dissolved oxygen and, consequently, it can eutropize the water in the tanks, which requires greater artificial aeration (Azevedo et al., 2016).

In a condition of anemia and hypoglycemia due to malabsorption of iron, malformation of erythrocytes or hemolysis and inhibition of hemoglobin synthesis, they cause stressful problems similar to hyperglycemia. This is proof of the importance of glycemic balance for good animal performance (Cerdeira, 2016). The glucose values of the fish, created in systems without aeration such as high stocking density and with two aeration regimes, have been altered, which corroborates the hematological results described above and the values of total proteins and cholesterol, in which it is not. demonstrated a need to increase the metabolic demand of fish (Sampaio \& Freire, 2016). In a study of the effect of therapeutic baths with formalin on stress indicators in tambaqui, similar averages values for glucose were found to be $78.96 \mathrm{mg} \mathrm{dL}^{-1}$ and $70.95 \mathrm{mg} \mathrm{dL}^{-1}$ at 30 minutes of exposure to formalin and recovery time (Araújo et al., 2004). 
Analyzing the environmental effect of glucose on stress in tilapia (Oreochromis niloticus) with an average of $63 \mathrm{mg}$ $\mathrm{dL}^{-1}$ for isolated fish and $0.68 \mathrm{mg} \mathrm{dL}^{-1}$ for those subjected to stress, the values of glucose concentrations were lower than 30 cultivation days (Merighe et al., 2004). For fish in tanks with aeration, the glucose concentration was similar (p>0.05). For fish in the tank without aeration, the glucose concentration was different $(\mathrm{p}<0.05)$ (Merighe et al., 2004). Glucose levels are used to assess the intensity of stress in fish, therefore, values below $72 \mathrm{mg} \mathrm{dL}^{-1}$ are indicative of animals without stress (Inoue et al., 2008). It can then be suggested that at 30 days of cultivation the animals in the aerated tank did not show symptoms of stress or were less susceptible to the stressful situation.

After 60 days of treatment for the aerated tank, Araújo et al. (2004) obtained values of $125,51 \mathrm{mg} \mathrm{dL}^{-1}$ when the fish were exposed to formalin for 30 minutes, being similar to this work, in which the plasma glucose concentrations were $124.58 \mathrm{mg} \mathrm{dL}^{-1}$. In addition, it is assumed that fish were more stressed in this phase according to the increase in glucose obtained through analysis, because in response to stress, glucose mobilization occurs as a averages to provide extra energy to the animal, for that it can overcome the imposed disorder (Barton, 2002; Schreck \& Tort, 2016).

In stressful situations, blood glucose concentrations in tropical fish increase rapidly as a physiological defense mechanism, since the organism is preparing to escape or fight, requiring an energy source that is easily metabolized and immediately used (Cerdeira et al., 2018). Therefore, the plasma glucose concentration is used as one of the main stress indicators in fish, especially because the values remain high for longer in stressed fish (McCormick et al., 2013). It can vary according to the stressful stimulus to which they are submitted and the environment in which they are maintained.

The stress response in fish includes an increase in the rate of oxygen uptake by the gills, as a result of increases in the ventilatory rate of gill blood flow, diffusion capacity and oxygen transport through the blood (Martins et al., 2004; McCormick et al., 2013; Burgos-Aceves et al., 2019). Regarding the average glucose values at 90 days of culture, similar values were found for blood glucose of $90 \mathrm{mg} \mathrm{dL}^{-1}$, which corroborates the concentration found of $90.44 \mathrm{mg} \mathrm{L}^{-1}$ for fish in the aerated tank (Cipriano et al., 2016). For pond fish without aeration, similar average values of $101.40 \mathrm{mg} \mathrm{dL}^{-1}$ were found for glucose, with $96.65 \mathrm{mg} \mathrm{dL}^{-1}$ evaluating the feeding frequency for juveniles of C. macropomum (Bezerra et al., 2014).

The study of hematological variables is of importance as a averages to aid diagnosis and health status of fish. Because erythrocytes are the most numerous cells in the blood and have the function of transporting gases, especially oxygen (TavaresDias et al., 2008), the transport of these gases is a function of hemoglobin, and their reduction is indicative of anemia. The decrease in the hemoglobin concentration in the blood of fish, which is usually caused by the toxic effect on the branchial lamellae, therefore, dissolved oxygen can also be an indicator of confirmation of anemia (Serezli et al., 2011).

The hematocrit, hemoglobin concentration and erythrocyte count can also be indicators of the fish's oxygen transport capacity, allowing to establish relationships with the oxygen concentration available in the breeding tanks (Chamy et al., 2015). The average values for erythrocytes and hemoglobin found (Table 1) are higher for erythrocytes and similar for hemoglobin (Aride et al., 2017), when hematological parameters of C. macropomum were evaluated and average values of 2.83 and $11.30 \mathrm{mg} \mathrm{dL}^{-1}$, respectively.

The difference in the number of erythrocytes between the two extremes, hyper and hypoglycemia seems to compromise the efficiency of oxygen transport to fish tissues, because the animals did not present the same stressful intensities and hematological conditions, also confirmed by the values of the hematimetric indices (VCM and HCM) (Azevedo et al., 2016). The changes in these blood parameters may indicate a response to stress, pointing to a lower oxygen transport capacity from the blood to the tissues (Vikesa et al., 2017). Under chronic conditions of low ODW levels, fish develop tertiary stress immune responses, such as the immunosuppression that favors the onset of disease (Baldisserotto, 2013). As a result, some diseases were detected, mainly in cases of high stocking densities (biomass), excess organic matter and toxic gases inside the tank, which contribute to poor water quality and, consequently, reflect on the health status of the fish (Tavares-Dias et al., 
2014). There is a higher occurrence of diseases when there are situations of hypoxia in cultivation, and consequently, the negative effects of stress. Therefore, proving the demanding need for artificial aeration in densification of fish in cultivation tanks (Cerdeira, 2016).

\section{Conclusions}

Due to the growing demand for fish in the Amazon, the volume of fish production has intensified, however, tambaquis confined to high densities without efficient aeration tend to physiological imbalance, making cultivation unviable. For this reason, artificial aeration increases the productive zootechnical performance of tambaqui (C. macropomum), especially at 60 days of cultivation, as it provides less stress. The physical-chemical parameters of the water were found in accordance with the recommended for the cultivation of tambaqui. Because, the presence of the aerator was efficient to improve water quality. Which provided the fish with more comfortable conditions.

The use of aeration for Amazonian fish, grown in excavated ponds, can keep the glucose concentrations lower, providing greater comfort to the fish, and may influence their productive performance. For future studies, it is suggested evaluations in the larval and final phases are suggested under more prolonged administration.

\section{References}

Aerts, J., Metz, J. R., Ampe, B., Decostere, A., Flik, G., \& Saeger, S. (2015). Scales Tell a Story on the Stress History of Fish. PLOS ONE, 10(4), e0123411. $10.1371 /$ journal.pone. 0123411

Araújo, L. D., Chagas, E. C., Gomes, L. C., \& Brandão, F. R. (2004). Efeito de banhos terapêuticos com formalina sobre indicadores de estresse em tambaqui. Pesquisa Agropecuária Brasileira, 39(3), 217-221. 10.1590/S0100-204X2004000300003

Aride, P. H. R., Oliveira, A. M., Batista, R. B., Ferreira, M. S., Pantoja-Lima, J., Ladislau, D. S., Castro, P. D. S., \& Oliveira, A. T. (2017). Changes on physiological parameters of tambaqui (Colossoma macropomum) fed with diets supplemented with Amazonian fruit Camu camu (Myrciaria dubia) Brazilian Journal of Biology, 78(2). 10.1590/1519-6984.169442

Azevedo, T. M. P., Albinati, R. C. B., Guerra-Santos, B., Pinto, L. F. B., Lira, A. D., Medeiros, S. D. C. \& Ayres, M. C. C. (2016). Reference values of the hematological paramaters of Oreochromis niloticus (Linaeus, 1758) cultivated in network tanks in Paulo Afonso, in the state of Bahia. Brazil. Brazilian Journal of Aquatic Science and Technology, 20(2). 10.14210/bjast.v20n2.4588

Baldisseroto, B. (2013). Fisiologia de peixes aplicada à piscicultura: Universidade Federal de Santa Maria.

Barton, B. A. (2002). Stress in fishes: a diversity of responses with particular reference to changes in circulating corticosteroids. Integrative and Comparative Biology, 42. 10.1093/icb/42.3.517

Bezerra, S. K., Souza, R. C., Melo, J. F. B., \& Campeche, D. F. B. (2014). Growth of tambaqui fed with different concentrations of manga and protein meal in feed. Archivos de Zootecnia, 63, 244. 10.4321/S0004-05922014000400003

Bjornsson, B. T., Johansson V., \& Benedet, S. (2002). Growth hormone endocrinology of salmonids: regulatory mechanisms and mode of action. Fish Physiology and Biochemistry, 27, 227-242.

Cavali, J., Dantas-Filho, J. V., Nóbrega, B. A., Andrade, L. H. V., Pontuschka, R. B., Gasparotto, P. H. G., Francisco, R. S., Campeiro Junior, L. D., \& Porto, M. O. (2020). Benefits of Adding Virginiamycin to Arapaima gigas (Schinz, 1822) Diet Cultivated in the Brazilian Amazon. Scientifica, 2020. $10.1155 / 2020 / 5953720$

Cavero, B. A. S., Rubim, M. A. L., \& Pereira, T. M. (2009). Criação comercial do tambaqui Colossomama cropomum (Cuvier, 1818). In: Tavares-Dias, M. (Org.). Manejo e sanidade de peixes em cultivo: EMBRAPA; p.33-46.

Cerdeira, K. A., Souza, K. J. N. S., Ferreira, J. B., Zampar, A., Ono, E. A., \& Affonso, E. G. (2018). Soybean meal in diets for juveniles of pirarucu. Boletim do Instituto de Pesca, 44(3). 10.20950/1678-2305.2018.318

Chamy, M. N. C. L., Souza, R. P., Costa, A. G. \& Tavares-Dias, M. (2015). Hematologia do Mylossoma duriventris (Serrasalmidae) da bacia do rio Solimões, Amazônia Central, Brasil. Revista de Veterinária e Zootecnia 22, 597-606.

Chagas, E. C., Gomes, L. C., Junior, H. M., \& Roubach, R. (2007). Productivity of tambaqui raised in a nursery with different feeding rates. Ciência Rural 37, $1109-1115$.

Cipriano, F. S., Lima, K. S., Souza, R. H. B., Tonini, W. C. T., Passinato, E. B., \& Braga, L. G. T. (2016). Digestibility of animal and vegetable protein ingredients by pirarucu juveniles, Arapaima gigas. Revista Brasileira de Zootecnia, 45(10). 10.1590/S1806-92902016001000001 
Cruz, C. D. (2013). Genes: a software package for analysis in experimental statistics and quantitative genetics. Acta Scientiarum: Agronomy, 35(3), 271-276. 10.4025/actasciagron.v35i3.21251

FAO. (2018) Food and Agriculture Organization of the United Nations. Fishery and aquaculture statistics 2018. Roma: FAO yearbook.

Fuentes, E. N., Valdés, J. A., Molina, A., \& Björnsson, B. T. (2013). Regulation of skeletal muscle growth in fish by the growth hormone - Insulin-like growth factor system. General and Comparative Endocrinology, 192, 136-148. 10.1016 j.ygcen.2013.06.009

Garcia-Navarro, C. E. K. (2005). Manual de Hematologia Veterinária: Varela; 169p.

Goldenfarb, P. B., Bowyer, F. P., \& Hall, E. (1971). Reproducibility in the hematology laboratory: the microhematocrit determination. American Journal of Clinical Pathology, 56, 35-39.10.1093/ajcp/56.1.35

IGFA (2001). Internacional Game Fish Association. Database of IGFA angling records until 2001: IGFA.

Inoue, L. A. K. A., Moraes, G., Iwama, G. K., \& Afonso, L. O. B. (2008). Physiological stress responses in the warm-water fish matrinxã (Brycon amazonicus) subjected to a sudden cold shock. Acta Amazonica, 38, 603-610. 10.1590/S0044-59672008000400002

Lima, E. C. R., Souza, R. L., Wambach, X. F., Silva, U. L., \& Correia, E. S. (2015). Culture of the Nile tilapia (Oreochromis niloticus) in biofloc system with different stocking densities. Revista Brasileira de Saúde e Produção Animal, 16(4). 10.1590/S1519-99402015000400018

Martins, M. L., Tavares-Dias, M., Fujimoto, R. Y., Onaka, E. M., \& Nomura, D. T. (2004). Hematological alterations of Leporinus macrocephalus (Osteichthyes: Anostomidae) naturally infected by Goezia leporini (Nematoda: Anisakidae) in fish pond. Arquivo Brasileiro de Medicina Veterinária e Zootecnia, 56, 640-646. 10.1590/S0102-09352004000500011

Martins, L. P., Franco, V., Dantas Filho, J. V., \& Freitas, C. O. (2020). Economic viability for the cultivation of tambaqui (Colossoma macropomum) in na excavated tank in the municipality of Urupá, Rondônia-Brazil. Revista de Administração e Negócios da Amazônia, 12(2). 10.18361/2176-8366/rara.v12n2p6489

McCormick, S. D., Sheehan, T. F., Bjornsson, B. T., Lipsky, C., Kocik, J. F., Regish, A. M., \& O’Dea, M. F. (2013). Physiological and endocrine changes in Atlantic salmon smolts during hatchery rearing, downstream migration and entry into the ocean. Canadian Journal of Fisheries and Aquatic Sciences, 70 , 105118. 10.1139/cjfas-2012-0151

Meante, R. E. X., \& Dória, C. R. C. (2017). Characterization of the fish production chain in the state of Rondônia: development and limiting factors. Revista de Administração e Negócios da Amazônia, 9(4): 164-181. 10.18361/2176-8366/rara.v9n4p164-181

Merighe, G. K. F., Pereira, S. E. M., Negrão, J. A. \& Ribeiro, S. (2004). Efeito da Cor do Ambiente sobre o Estresse Social em Tilápias-do-Nilo (Oreochromis niloticus). Revista Brasileira de Zootecnia, 33, 828-837. 10.1590/S1516-35982004000400002

Oliveira, R. P. C., Silva, P. C., Brito, P. P., Gomes, J. P., Silva, R. F., Silveira Filho, P. R., \& Roque, R. S. (2010). Variáveis hidrológicas físico-químicas na criação da Tilápia-do-nilo no sistema raceway com diferentes renovações de água. Ciência Animal Brasileira, 11(3), 482-487. 10.5216/cab.v11i3.3847

Oliveira, R. P. C., Silva, P. C., Pádua, D. M. C., Aguiar, M., Maeda, H., Machado, N. P., Rodrigues, V., \& Silva, R. H. (2007). Efeitos da densidade de estocagem sobre a qualidade da água na criação do tambaqui (Colossoma macropomum Cuvier, 1818) durante a segunda alevinagem em tanques fertilizados. Ciência Animal Brasileira, 8(4), 705-711.

Pádua, S. B., Dias Neto, J., Sakabe, R., Claudiano, G. S., Chagas, E. C., \& Pilarski, F. (2013). Hematologic variables in tambaquis anesthetized with clove oil and benzocaine. Pesquisa Agropecuária Brasileira, 48(8), 1171-1174. 10.1590/S0100-204X2013000800056

Porto, M. O., Oliveira, J. D., Cavali, J., Dantas Filho, J. V., Soares, N. T. D., Gasparotto, P. H. G., \& Ferreira, E. (2020). Food frequency for tambaquis Colossoma macropomum (CUVIER, 1818) cultivated in na Amazonic Research Center. Revista de Administração e Negócios da Amazônia, 12(1). 10.18361/2176- 8366/rara.v12n1p108-121

Oliveira, E. G., Pinheiro, A. B., Oliveira, V. Q., Silva Júnior, A. R. M., Moraes, M. G., Rocha, I. R. B., Sousa, R. R., \& Costa, F. H. F. (2012). Effects of stocking density on the performance of juvenile pirarucu (Arapaima gigas) in cages. Aquaculture, 370-371, 96-101. 10.1016/j.aquaculture.2012.09.027

Ozovehe, B. N. (2013). Growth performance, haematological índices and some biochemical enzymes of juveniles Clarias gariepinus (Bruchel, 1822) fed varying levels of Moringa oleífera lef meat diet. Journal of Aquaculture Research \& Development, 4(2). 10.4172/2155-9546.1000166.

Paz, A. L., \& Val A. L. (2018). Manipulation of growth of the Amazonian fsh tambaqui, Colossoma macropomum (Characiformes: Serrasalmidae): analysis of physiological and zootechnical aspects. Acta Amazonica, 48, 197-206.10.1590/1809-4392201800181

Peixe, B. R. Associação Brasileira da Piscicultura (2020). Anuário 2020: Peixe BR da Piscicultura: PEIXE BR; 136p.

Pereira, S. A., Shitsuka, D. M., Parreira, F. J. \& Shitsuka, R. Metodologia da pesquisa científica. UFSM, NTE; 2018.

Ranzani-Paiva, M. J. T., Pádua, S. B., Tavares-Dias, M., \& Egami, M. I. (2013). Métodos para análises hematológicas em peixes: Eduem.

Sampaio, F. D. F. \& Freire, C. A. (2016). An overview of stress physiology of fish transport: changes in water quality as a function of transport duration. Fish and Fisheries, 1-8. 10.1111/faf.12158

Schmidt-Nielsen, K. (1986). Fisiologia animal: adaptação e meio ambiente. Santos 600p.

Serezli, R., Akhan, S. and Delihsan-Sonay, S. (2011). Acute effects of copper and lead on some blood parameters on coruh trout (Salmo coruhensis). African Journal of Biotechnology, 10, 3204-3209. 10.5897/AJB10.2505 
Research, Society and Development, v. 10, n. 1, e32310111759, 2021 (CC BY 4.0) | ISSN 2525-3409 | DOI: http://dx.doi.org/10.33448/rsd-v10i1.11759

Schreck, C. B., \& Tort, L. (2016). The concept of stress in fish. Biology of Stress in Fish - Fish Physiology, 1-34. 10.1016 / b978-0-12-802728-8.00001-1

Silva, A. D. R., Santos, R. B., Bruno, A. M. S. S., \& Soares, E. C. (2013). Cultivo de tambaqui em canais de abastecimento sob diferentes densidade de peixes. Acta Amazonica, 43, 517-523. 10.1590/S0044-59672013000400014

Silva, C. A., \& Fujimoto, R. Y. (2015). Crescimento de tambaqui em resposta a densidade de estocagem em tanques-rede. Acta amazônica, 45(3), 323-332. $10.1590 / 1809-4392201402205$

Silva, C. D. M., Pires, C. R. F., Sousa, D. N., Chicrala, P. C. M., \& Santos, V. R. V. (2016). Evaluation sensory of canned matrinxã (Brycon amazonicus) in vegetable oil. Journal of Bioenergy and Food Science, 3, 161-169. 10.18067/jbfs.v3i3.96

Silva, J. A. M., Pereira-Filho, M., Cavero, B. A. S., \& Oliveira, P. M. I. (2007). Digestibilidade aparente dos nutrientes e energia de ração suplementada com enzimas digestivas exógenas para juvenis de tambaqui Colossoma macropomum (Cuvier, 1818). Acta Amazônica, 37(1), 157-164. 10.1590/S004459672007000100021

Tanveer, M., Roy, S. M., Vikneswaran, M. P., Renganathan, P., Balasubramanian, S. (2018). Surface aeration systems for application in aquaculture: A review. International Journal of Fisheries and Aquatic Studies, 6(5): 342-347.

Tavares-Dias, M., Moraes, F. R., \& Imoto, M. E. (2008). Hematological parameters in two neotropical fresh water teleost, Leporinus macrocephalus (Anostomidae) and Prochilodus lineatus (Prochilodontidae). Bioscience Journal, 24(3), 96-101.

Tavares-Dias, M., \& Sandrim, E. F. S. (1998). Características hematológicas de teleósteos brasileiros: Série vermelha e dosagens de cortisol e glicose do plasma sanguíneo de espécimes de Colossoma macropomum em condições de cultivo. Acta Scientiarum 20, 157-160. 10.4025/actascibiolsci.v20i0.4466

Tavares-Dias, M., Oliveira, M. S. B., Gonçalves, R. A., \& Silva, L. M. A. (2014). Ecology and seasonal variation of parasites in wild Aequidens tetramerus, a Cichlidae from the Amazon. Acta Parasitologica, 59, 158-164. 10.2478/s11686-014-0225-3

Viseka, V., Nankervis, L. \& Hevroy, E. M. (2017). High dietary level simulates growth hormose receptor and feed utilization in large Atlantic salmon (Salmo salar L.) under hypoxic conditions. Aquaculture Nutrition, 23, 1193-1203. 10.1111/anu.12488 